\title{
Looking for the women in Baron and Taylor's (1969) Educational administration and the social sciences
}

Kay Fuller*

School of Education, University of Birmingham, Birmingham, UK

A search for women in Baron and Taylor's (1969) Educational administration and the social sciences [London: The Athlone Press] using feminist poststructural discourse analysis (FPDA) has revealed a changing discourse about gendered educational administration over the course of 50 years. Whilst few women are featured in the text itself, citations of women's writing surface the historical contributions of women as headmistresses and public servants. Women who have cited the text since its publication have challenged gendered theory and academic writing conventions. FPDA is used to explore the gendered educational administration discourse through the intertextuality of academic writing. Fluctuations between powerfulness and powerlessness are revealed depending on the socio-political context and women's circumstances.

Keywords: gender; educational administration; feminist poststructural discourse analysis; headmistresses; public servants; academic writing

\section{Introduction}

Baron and Taylor's (1969) book Educational administration and the social sciences was written at a time of great social change. The women's movement underway in 1969 is usually located in the second wave feminism that championed women's rights. Feminist academics and teachers were turning their attention to the presence (or absence) of women in educational textbooks and materials. Gender theory was understood to refer to theories of equality or difference based on essentialist differences between women and men (see Scott 1988). By contrast, a search for women in the text, undertaken in the twenty-first century, does not imply they comprise a single homogenous group based on biological sex.

This paper reports findings from an analysis of Baron and Taylor's (1969) book using the principles of feminist poststructural discourse analysis (FPDA). A content analysis of the text itself develops into a poststructural

\footnotetext{
*Email: k.e.fuller@bham.ac.uk 
analysis of its relationship with related texts to incorporate a consideration of metaphors, forms of relationship and patterns of power and desire identified in those texts (Walkerdine 1990). This approach has surfaced a changing discourse regarding gender and educational administration as it has developed over time. More usually used in the analysis of spoken text, FPDA is used for the first time to look at gendered educational leadership through the intertextuality of academic texts written over the course of half a century. The paper is made up of four further sections. The next gives a brief overview of the sociopolitical context in 1969. There follows an outline of how the text was analysed. The fourth section presents the findings regarding gendered language, the representation of women and the intertextuality between the book and women's academic writing. I go on to discuss the changing discourse about gender and educational administration as it emerged from the analysis of the written texts.

\section{The socio-political context}

In 1969, few women were engaged in national and international politics. Barbara Castle held office in the UK, with only three women Cabinet predecessors (including Ellen Wilkinson, Minicter for Education 1945-1947) (Centre for Advancement of Women in Polit $@$ In world politics, Sirimavo Bandaranaike was prime minister of Ceylon (Sri Lanka from 1972), Indira Gandhi prime minister of India and Golda Meir premier of Israel (Williams 1998). In the USA, Richard Nixon was embarrassed into setting up the Task Force on Women's Rights and Responsibilities to recruit and train women for upperlevel governmental positions (Stout 2012).

In 1969, Friedan's (1963) The feminine mystique had already described women's widespread unhappiness. Some women were leading local Women's Liberation Movement groups developing across the UK (Feminist Archive North). At the same time political reforms were designed to impact on women's everyday lives with regard to divorce and abortion, for example. Oral contraception was increasingly accessible. Second wave feminism was underway. The Stonewall Riots in New York marked the starting point of the modern gay rights movement, although the UK Homosexual Law Reform Act had already passed in 1967. In the USA, Civil Rights legislation from the 1950s was already designed to allow desegregation of schools and impact on legal representation and voting rights. Nevertheless, Civil Rights remained a huge issue and in 1969, Coretta Scott King was the first woman to speak from the pulpit of St Paul's Cathedral in London.

Against this socio-political backdrop, Baron and Taylor (1969, p. 6) suggested that the field of educational administration encompassed, 'the activities of Parliament at one end of the scale and the activities of any home with children and students at the other'. However, such an inclusive approach in 
terms of field position (Gunter 2002a, 2003b) did not extend to explicitly include women in positions of power or the problematisation of gendered theory (Gunter 2000). In this paper, I specifically look for the women in Educational administration and the social sciences (Baron and Taylor 1969) using FPDA. In the section that follows I provide an overview of gender theory and an account of the frames of analysis using FPDA.

\section{Gender theory}

The development of feminism has been described in terms of 'waves' associated with historical movements. 'First wave' feminism is usually associated with the women's suffrage movements of the nineteenth and early twentieth centuries. The 'second wave' feminism of the late 1960s and 1970s that championed women's rights has been criticised for perpetuating a notion of universal womanhood through 'racist, classist, and colonialist assumptions in attempting to "speak for" all women' and seen to 'privilege[d] the interests of white, middle-class, heterosexual women' (Ingraham 1994, p. 204). 'Third wave' feminism from the 1990s refers to theory that incorporates constructivist principles and poststructuralism (Baxter 2003). It resists essentialism. Although these historical 'waves' are widely accepted and referred to, this notion has been critiqued. Baxter (2003) challenges whether feming history should be characterised chronologically as historical 'waves' 1 arguing key feminist writers have combined modernist and post-structuralist thinking in a single text. Feminist theorists might rather conceptualise post-structuralist feminism as 'one of several linked but competing theoretical strands within feminist history' (Baxter 2003, p. 5). Gender theorists have long recognised the impact of intersectionality (Crenshaw 1991), the multiplicity of 'femininities' (Connell 2005) and the performativity of gender disconnected from biological sex (Butler 1990, 2004). Roth (2004, p. 7) claims second wave feminism has been 'whitewashed' in part by feminist scholars, albeit unintentionally. Thompson (2002, p. 337) sets the record straight by including 'women of color and white antiracist women [to illuminate] the rise of multiracial feminism'. There is a precedent for recovering the histories of marginalised groups of women. FPDA is a supplementary form of discourse analysis that resonates with aspects of critical discourse analysis (CDA) (Baxter 2003). Each sees discourse as social practice; recognises the performative, diverse and multiple nature of identities; acknowledges the construction of meaning within context-specific settings; has an interest in deconstruction in working out binary power relations; recognises interdiscursivity and requires continuous self-reflexivity about values and assumptions made by discourse analysis (Baxter 2008). A characteristic of CDA is its concern with social life and the role of discourse in it (Blackledge 2005). Whilst requiring 'very close attention to the details of textual features' (Blackledge 2005, p. 3) it is not solely 
concerned with language and language use. It opposes those who 'abuse text and talk in order to establish, confirm or legitimate their abuse of power' (Blackledge 2005, p. 3). Thus CDA links linguistics with sociology. It is through spoken and written texts that we learn:

how to recognize, represent, and 'be', ... that cultural categories and versions of children, students, adults, and workers are built up, established in a hierarchical social grid of the 'normal', and taught and learned: categories of gender identity, sexual desire, ethnic identity, class and work, regional solidarity, citizenship and national identity. (Luke 1995, p. 14)

The CDA of spoken and written texts in education provides evidence of 'the exclusion and silencing of issues of difference under the auspices of a colorblind, gender-blind, homogenous approach to curriculum and instruction' (Luke 1995, p. 38). It follows that an analysis of Educational administration and the social sciences (Baron and Taylor 1969) might reveal the dominant gendered discourse through which readers 'learn to recognize, represent, and "be" (Luke 1995, p. 14) educational administrators. Here, I take up the challenge to apply FPDA methods to written text (Baxter 2003).

The feminist focus has arisen from an invitation to look at Baron and Taylor's (1969) book from the perspective of 'the missing woman'. There is a 'quest to release the voices of those who have been silenced or suppressed' (Baxter 2003, p. 66). FPDA 'means giving space to marginalised or silenced voices (such as certain girls who say little in classroom settings, or those women whose voices are overlooked or silenced in management settings)' (Baxter 2008, p. 247). There is a precedent for recovering marginalised histories of women in English educational administration (Grace 1995). Pedersen (1987) traced the shift from 'lady-teachers' (p. 102) to educated 'professional 160 wom(en)' (p. 171) and there are accounts of women leading high schools in the nineteenth century (Glenday and Price 1974, Watts 1998). In seeking out women I focus on the binary power relations in educational administration. However, FPDA recognises complexity rather than polarisation of subjects of study:

males are not polarised as villains and females as victims in any oppositional sense, nor even to presume that women as a category are necessarily powerless, disadvantaged or oppressed by 'the other'. Rather, it argues that female subject positions are complex, shifting and multiply located. (Baxter 2008, p. 248)

Rather, by engaging in competing discourses we shift constantly between positions of powerfulness and powerlessness. The declaration of an ideological motive in looking specifically for women in the text resonates with the FPDA principle of self-reflexivity (Baxter 2003). My interpretation of women's subject positions is open to debate, it is informed by my twentyfirst century understanding of gendered educational leadership as a white, 
now middle-class, academic who was once deputy headteacher of a secondary school (see Fuller 2013).

I take a deconstructionist approach in recognising the shifting property of discourses within the text(s) as they are imbued with meaning by the interdiscursivity of multiple readers and writers. Baxter (2008, p. 248) contends:

speakers do not exist outside discourse. From the moment we are born, we enter a social world that is infused by competing discourses. We make sense of our existence through such discourses - pre-existing knowledge systems which constantly mediate our thoughts and experiences.

It is because a piece of written text or 'a stretch of speech or talk is continuously reconstructed or reproduced through discourse, never outside it' (Baxter 2008, p. 248) that the distinction between text and context is 'collapsed by FPDA in favour of the concept of interdiscursivity, where one discourse is always negotiated, challenged, evolved and adjusted through the lens of other discourses' (Baxter 2008, p. 248). As the focus of this special edition the discourses in Educational administration and the social sciences (Baron and Taylor 1969) are deconstructed and reconstructed through the lens of the various contributing authors as well as authors who have cited the work since publication.

Thus, women are sought in the text through the micro-analysis of language used by contributing authors; the representation of women in terms of position, activities and possessions; and the intertextuality 'in which texts are always infused and inscribed with traces of other texts' (Baxter 2003, p. 53). The relationship between the book and women's writing is explored in relation to gender and educational administration. In the section that follows I present the findings of each focused analysis in turn.

\section{Findings}

\section{Language - gendered nouns and pronouns}

Women are mentioned eight times in Educational administration and the social sciences (Baron and Taylor 1969) (see Table 1). No author used feminine personal pronouns as 'she', 'her' or 'herself' at all.

Almost all the male contributing authors specifically mention men (Table 1). Burnham (1969) indicates he refers throughout to 'a headmaster' (p. 73). However, some references are to generic notions of 'rational man' and 'social man' (Hoyle 1969, p. 36); 'manpower planning' (Peston 1969, p. 64);

215 'Englishman' (Taylor 1969, p. 97); an 'employer's man' (Owen 1969, p. 131) and man-machine (Austwick 1969, p. 146). Ideas differed 'from man to man' (Owen 1969, p. 130). All, except Eggleston (1969), who adopts gender neutrality, use the masculine pronouns 'he', 'him', 'himself' and 'his' throughout. Other authors than Eggleston (1969) use gender neutral terms such as 'administrator', 'headteacher', 'teacher' and 'student', but the 
Table 1. References to women and men in Educational administration and the social sciences (Baron and Taylor 1969).

\begin{tabular}{|c|c|c|c|c|c|c|c|}
\hline Chapter & Author & Reference to women & No. & $\begin{array}{l}\text { Feminine } \\
\text { pronouns }\end{array}$ & Reference to men & No. & $\begin{array}{l}\text { Masculine } \\
\text { pronouns }\end{array}$ \\
\hline 1 & Baron & & 0 & 0 & Headmaster (p. 3 ; twice on pp. $6,7,15)$ & 5 & 11 \\
\hline 2 & Eggleston & & 0 & 0 & & 0 & 0 \\
\hline 3 & Hoyle & & 0 & 0 & $\begin{array}{l}\text { Rational man (p. 36) } \\
\text { Social man (p. 36) }\end{array}$ & 2 & 8 \\
\hline 4 & Peston & Headmistress (p. 70) & 1 & 0 & Manpower planning (p. 64) & 1 & 8 \\
\hline 5 & Burnham & $\begin{array}{l}\text { Senior mistress (pp. 74, 86) } \\
\text { Senior woman tutor (p. 75) } \\
\text { Dinner lady (p. 75) } \\
\text { The women's guild (p. 90) }\end{array}$ & 5 & 0 & $\begin{array}{l}\text { Headmaster (pp. 73, 80, 83) } \\
\text { Housemasters (pp. 74, 75, 86) } \\
\text { Careers master (p. 75) } \\
\text { Science master (p. 75) } \\
\text { Games master (p. 75) } \\
\text { Physics masters (p. 75) } \\
\text { Groundsman (p. 75) } \\
\text { The old man (p. 76) }\end{array}$ & 12 & 74 \\
\hline 6 & $\begin{array}{l}\text { Taylor } \\
2 \\
2\end{array}$ & $\begin{array}{c}\text { Women's education } \\
\text { (twice on p. 107) } \\
0\end{array}$ & 2 & 0 & Englishman (p. 97) & & \\
\hline 7 & Owen & & 0 & 0 & $\begin{array}{l}\text { Man to man (p. 130) } \\
\text { Employer's man (p. 131) } \\
\text { One man's idea (p. 135) }\end{array}$ & 3 & 59 \\
\hline 8 & Austwick & & 0 & 0 & Man-machine (p. 146) & 1 & 15 \\
\hline 9 & Myers & & 0 & 0 & & 0 & 6 \\
\hline 10 & Wheeler & & 0 & 0 & & 0 & 18 \\
\hline Total & & & 8 & 0 & & 25 & 204 \\
\hline
\end{tabular}


265 subsequent use of the masculine pronoun frequently reveals a gendered conception of each.

This analysis of masculine noun and pronoun usage makes clear how far men writers ensured the dominance of men in the field. It appears education was for boys and taught and organised by men. However, Bondi (1997) sees the eventual loss of legitimacy in such use of masculine pronouns as a pyrrhic victory. The rationale for using non-sexist, gender-neutral, gender inclusive phraseology remains problematic:

It is just the conventions of correspondence that are in question in debates about sexism in language. From this perspective, it is linguistic representations of knowledge that are flawed by gender biases rather than knowledge itself. (Bondi 1997, p. 248)

The requirement to use non-sexist terminology might encourage 'superficial adjustments' (Bondi 1997, p. 249) rather than problematise gendered knowledge and knowledge production.

\section{Representation of women - position, activities and possessions}

\section{Position}

Women and men are represented as teaching, non-teaching staff and administrators. Four roles for women comprise 'headmistress of an infant school' (Peston 1969, p. 70); 'senior mistress', 'senior woman tutor' and 'dinner lady' (Burnham 1969, p. 75). Peston (1969) polarises macro- and micro-level discourse from the Department of Education and Science as 'one extreme' (p. 70) and that of the infant school headmistress 'at the other', alongside the head of a university department. The woman holds a position of authority seemingly alongside a man; heads of university departments and leaders in higher education are still likely to be men (see Acker 2012, Morley 2013a, 2013b). The assumption that an infant school headteacher was a woman is common (Gray 1989). Indeed, women still outnumber men as nursery and primary school headteachers (Department for Education 2012). However, there remains a gap in representation with women making up $86 \%$ of the nursery and primary teaching workforce but only $71 \%$ of headteachers (Department for Education 2012). Burnham (1969, p. 74) includes the contribution of the 'senior mistress' in his discussion of a team approach. Whilst she holds a senior position, Burnham's constant reference to the 'headmaster' (p. 73) limits this woman's career aspirations. The promotion of a woman as 'senior woman tutor to deal with the students' personal problems' (p. 75) suggests women might hold senior roles but only in relation to pastoral matters. The sexist division of labour in schools has been discussed elsewhere (see Ouston 1993). The 'dinner lady' is a member of the 'ancillary staff' who supports teaching staff (Burnham 1969). Women continue to dominate support staff positions in schools (see Fuller 2013). 
By contrast, men hold powerful positions as chiefs (Baron, Hoyle), heads (Baron, Hoyle, Burnham, Taylor, Owen, Wheeler), administrator (Baron, Peston, Burnham, Owen, Myers), leader (Burnham), decision-maker (Myers) and boss (Burnham). They are also secretary of the examining board (Baron), advisers (Owen), academics (Hoyle) and economists (Peston). In schools, they are deputy headteacher (Hoyle), teachers (Hoyle, Burnham, Owen, Austwick, Wheeler), masters (Burnham) and lecturer (Wheeler). Elsewhere men are superintendents (Burnham). Male ancillary staff are caretaker and groundsman (Burnham). Burnham (1969) acknowledges roles outside education as 'husband, father, uncle, lay preacher, examiner, secretary to the local tennis club, freemason' (p. 80). Recent research into the multiple roles of men and women headteachers has revealed the fluidity and complexity of their interaction with and impact on headship (Fuller 2013).

\section{Activities}

325 The one activity assigned to a woman was to 'deal with the students' personal problems' (Burnham 1969, p. 75). By contrast, the chief education officer 'present[s] his plans for secondary school reorganisation' (Baron 1969, p. 7); the secretary of the examining board 'devise[s] policy' (p. 7); and the headmaster 'draw[s] up detailed syllabuses and codes governing the performance of teaching duties' (p. 6) and sets policy for working with the Parent Teacher Association. The headteacher holds in his hands 'all matters relating to the internal organisation and discipline of his school' (Baron 1969, p. 6). Men make decisions (Hoyle 1969, Myers 1969, Wheeler 1969). This constitutes planning staff deployment, intervening and analysing problems with the help of economists (Peston 1969). Wheeler (1969, p. 180) enunciates as inevitable the 'assessment of performance which needs to be made to establish how successful or otherwise both he and the organisation are'. Burnham (1969, p. 73) represents each administrator bringing 'his own individual personality to bear on the role' so that 'actual role performance may be thought of as fusion of role expectations and "self". Each person "stamps the particular role he plays with the unique style of his own personality' (Burnham 1969, p. 73). The administrator is distanced from classroom and subject pedagogy but manages educational innovation that requires teachers to change their behaviours (Owen 1969).

\section{Possessions}

Having noted the absence of feminine personal pronouns, I was forced to focus on the possessive masculine pronoun to further reveal what women do not have. 'His' possessions can be categorised as positions, organisations, objects, activities, spaces, personal qualities, behaviours and people. Hoyle (1969, p. 41) refers to 'his rank' (of deputy headteacher) related to 'his latent power, the power which he assumes in the absence of the head, than his manifest day- 
to-day power'. Burnham (1969), Owen (1969) and Wheeler (1969) refer to 'his role'; Burnham (1969) to 'his authority' and Burnham (1969) and Owen (1969) to 'his position'. Organisations are 'his school' (Baron 1969, p. 6) and 'college organisation' (Burnham 1969, p. 75). Objects are 'his plans' (Baron 1969, p. 6), 'his objectives' (Myers 1969, p. 172), 'his money' (Owen 1969, p. 130) and metaphorically 'his hat' (Burnham 1969, p. 89). Activities include 'his actions' (Taylor 1969, p. 111), 'his usual functions' (Owen 1969, p. 131), 'his own work' (Owen 1969, p. 134) and 'his administration' (Owen 1969, p. 141); time is at 'his disposal' (Burnham 1969, p. 87). Wheeler (1969, p. 180) describes 'his participation', 'his function', 'his duties', 'his responsibilities', 'his decision-making' and 'his work'. Spaces are 'his office' (Baron 1969, p. 6) and 'his study' (Burnham 1969, p. 72). Personal qualities include Burnham's (1969) references to 'his' personality, and the way 'his' behaviour through gestures and responses indicates 'his degree of approval or disapproval' (p. 78) of the behaviour of others. He acknowledges 'his feelings' (p. 84) might influence decision-making and fulfilling 'his own personality needs' (p. 84) might impinge on the institutional requirements of his role. Owen (1969, p. 127) refers to 'his thinking', and 'his view' (p. 130) of innovation impacting on other aspects of administration. The shift from teacher to administrator is described as 'his translation' (p. 130). People belong to educational administrators as members of 'his committees' and 'his board', 'his clients' and 'his parent and teacher association' (Baron 1969, pp. 6-7). They are 'his staff' (Burnham 1969, p. 74, Hoyle 1969, p. 52, Taylor 1969, p. 111) and 'his colleagues' (Taylor 1969, p. 104). Only Owen $(1969$, p. 131) refers to 'his relationship with a lay education committee' to imply something other than ownership.

This analysis of the positions women hold, the activities they undertake and of their possessions reveals their powerlessness in comparison with men in the text. Gendered language results in the gendered production of knowledge that privileges men and disadvantages women. The book reflects the thinking around leadership and the position of women at the time. Any reference to social change is related to educational innovation and reorganisation rather than to challenging the positions of potentially marginalised groups such as women (Burnham 1969, p. 75). In the section that follows, the contributions of women academics referred to in Baron and Taylor (1969) and those who cite the book are considered through the analysis of the relationships between texts.

\section{Intertextuality - contributions of women academics}

Women have been difficult to find in this androcentric account of educational administration (Shakeshaft 1987). However, women academics are present in citations made by three authors. Use of authors' first names identifies them as women. Other women may have been missed because initials were used. Baron (1969) and Hoyle (1969) cite Banks (1955); Baron (1969) and Eggleston 
(1969) cite work co-authored by Valerie Chapman first published in 1965 (Donnison et al. 1970); and Baron (1969) cites Cruickshank (1963) and Phillips (1965).

Baron (1969) and Eggleston (1969) cite Donnison and Chapman's (1905 reprinted in 1970) case study of the reorganisation of secondary education. Although Eggleston (1969) refers to an $\rightarrow$ ier work co-authored by Valerie Chapman (Donnison and Chapman 1963, it is not listed in the references and she was almost written out of the references by his listing work by Donnison et al. (1965). The third edition (Donnison et al. 1970) identifies additional co-authors including Angela Sears. However, the chapter to which Baron (1969) and Eggleston (1969) directly refer does not feature any women. In other chapters highly educated women with considerable experience and expertise undertake social administration roles. Cruickshank (1963), Banks (1955) and Phillips (1965) write about women as headmistresses and public servants.

\section{Headmistresses}

Baron $(1969$, p. 5) refers to the role of pressure groups 'in policy formation and execution' that Cruickshank (1963) describes in her history of the partnership between church and state in English education. The political nature of educational administration is brought about by the 'complexity of relationships' and 'interplay of pressure groups and interest groups' (Baron 1969, p. 7). Such relationships are inevitably largely between powerful men in the maledominated church and state partnership that Cruickshank (1963) charted between 1870 and 1963. The 'dame schools' prior to that are described as 'poor joyless places run by pathetic old women or spiritless and disheartened men who had failed in other walks of life' (Cruickshank 1963, p. 19). This depiction of school administration prior to 1870 is one of powerlessness. It places powerless men alongside powerless women.

Baron (1969) and Hoyle (1969) value Banks' (1955) use of historical perspectives. Despite the general impression in Baron and Taylor's (1969) book that education was for boys and taught and organised by men, this intertextual exploration reveals Banks (1955) writes girls and women into her history of English secondary education. Women teach and work in educational administration at school and in professional associations. The Headmistresses' Association is cited, from 1908 onwards, as an influential group of women concerned with educational reform. The School Board expected headmistresses to exercise power (Incorporated Association of Headmistresses 1910, cited Banks 1955) (for further accounts of attitudes towards headmistresses, see Glenday and Price 1974). Various reports note the collective opinions of headmistresses about the education system, school organisation and the curriculum between 1908 and 1946. In 1926, they complained about the 'disinclination shown in many callings to allow women to rise beyond a modest position or to get a general grasp of the business, to which, whatever their abilities, they are 
attached in a very subordinate capacity' (Incorporated Association of Headmistresses 1926 cited Banks 1955, p. 195). They concerned themselves with women's career prospects. The individual voice of one headmistress, Sarah Burstall President of the Association of Headmistresses, is cited in 1910 with regard to the 'too academic character of secondary education' (Burstall 1910 cited Banks 1955, p. 74) as inadequate preparation for employment.

Baron (1969) linked Phillips' (1965) accounts of small social groups to educational administrators' thinking about committee, professional association and staff room relationships. Women feature in her writing as leaders in and outside schools. However, Phillips (1965) uses an idealised nuclear and extended family structure to identify group roles that perpetuate stereotyped sex roles. Freudian psychoanalysis alongside a sociological approach is used to identify group functions as instrumental (concerned with external relations) and expressive (concerned with the group's relations to one another). At the same time the nuclear family differentiates on a 'power dimension into leaders and followers' (Phillips 1965, p. 87). The 'father' is the 'leader', his 'sons' are 'followers' (p. 88). The 'mother' figure becomes the 'centre' or 'group maintainer'. These gendered roles were outdated in their infantilisation of group members/followers at the time of publication (see Friedan 1963 for a critique of Freud). Nevertheless, although apparently governed initially by biological sex these roles are not ultimately confined to it. The Student Chairman of the Council of a Women's Training College is described, 'the "parent" here is feminine she seems to be regarded principally as a father figure, as in status she is ...' (p. 93). Other women (cinema manageress, matron, lecturer) identified as 'officially a father' were seen to be performing 'equally as a "mother"' (p. 103). So too, men could be 'motherly':

the leaders should ideally be a man and the centre a woman. But in a one-sex group this is not possible, nor is it unusual to find men with 'motherly' impulses and women with leadership capacity .... Nor is it rare to find individuals capable of discharging both functions. (p. 131)

The 'grandfather' role describes a headteacher's management of 'his family of two generations' (p. 259) as staff and pupils. A new headteacher is a "'stepparent" by reason of her newness' (p. 255) and usurpation of her predecessor's leadership authority. Phillips (1965) implies these highly gendered roles are not solely linked to biological sex.

Phillips (1965) likens the headmistress of an independent school to the Victorian headmistresses Dorothea Beale and Frances Buss (see Pedersen 1987). There are accounts of headmistresses of various types of school. These women are described in terms of social class and personality. One came from, 'a highly cultured, upper-class family [and] is more conservative in her attitude, aristocratic in her dealings' (p. 251); another was 'very much county family ... had private income[s], dressed with expensive quietness' (p. 254). 
485 One was 'undeniably human and understanding beneath the veneer of formality' (p. 251) who despite willingness to review policy only allowed 'the views of younger members of staff [to filter] through slowly' (p. 251). Another headmistress enabled staff to vote on an initiative and was heavily defeated. A previous headmistress of a direct grant school had been remote in a 'saint-like' (p. 254) way. By contrast the headmistress of a girls' secondary school was afraid of 'alienating the affections of the girls' (p. 259) and undermined discipline. There is acknowledgement of the intersection or interaction between social class and gender. However, there is no mention of other facets of identity such as ethnicity, faith or sexuality though one account does acknowledge ethnic difference among women teachers.

Phillips' (1965) focus on the need for complementary approaches of leadership and group maintenance gives a powerful account of leadership that values consultation, democratic principles and care for the well-being of others. Her study recounts the unexpected emergence of a leader. The headmistress who enabled this allowed another:

'mother' to function, a subleader to emerge and a deviant [awkward staff member] to remove herself, recruiting over the years new members of staff whose values are her own, and taking advantage of every opportunity to build both a working and an expressive group with herself as leader and centre. (p. 276)

This description resonates with the approach that some newly appointed women headteachers have adopted in their leadership of male-dominated senior leadership teams (Fuller 2013).

\section{Public servants}

The newly established School Board of 1870 included 'some of the distinguished men and women of the time' (Cruickshank 1963, p. 38), including Emily Davies and Elizabeth Garrett 'women pioneers in public and professional

515 life' (p. 38) and campaigners for women's suffrage. Similarly, Phillips (1965) refers to Gertrude Denman as President of the Women's Institute. Women public servants of the twentieth-century feature in Banks' (1955) writing as educational reformer - non (1948), author of Three schools or one; Alice Bacon, Labour Member of Parliament (1945-1970) and Ellen Wilkinson Labour Minister for Education (1945-1947).

Thus, the women writers cited in Baron and Taylor (1969) wrote about women as educational administrators and public servants with an interest in educational administration at a high level. Having referenced this work by women about women, it is extraordinary that Baron (1969), Eggleston (1969) and Hoyle (1969) have otherwise excluded women completely. Further work by Banks (1982, 1999) and Banks and Banks (1964) reveals her continuing interest in feminist scholarship as an education sociologist (see also Martin 2008). 


\section{Intertextuality - citations by women academics}

A simple online search revealed 55 citations of Baron and Taylor's (1969) book including those by four women: Beryl Tipton (1985); Helen Gunter (2000, 2001, 2002a, 2002b, 2003a, 2004, 2005, 2012a, 2012b, 2012c, 2013, Gunter and Ribbins 2002, 2003a, 2003b, Ribbins and Gunter 2002); Tanya Fitzgerald (Gunter and Fitzgerald 2007, 2008) and Pat Thomson (Gunter and Thomson 2009, 2010). There are five dominant themes:

- the value of social sciences in educational administration research (Tipton 1985, Gunter 2001, 2002a, 2003a, 2005, Gunter and Ribbins 2003a, Gunter and Thomson 2009, 2010),

- the definition of field boundaries inclusive of a wide range of knowers, knowing and knowledge (Gunter 2002a, 2002b, 2003b, 2005, 2012a, 2012c, Gunter and Ribbins 2003b, Gunter and Fitzgerald 2007, 2008),

- the historical mapping of the field (Gunter 2001, 2002a, 2004, 2013, Gunter and Ribbins 2002, 2003a, 2003b, Gunter and Thomson 2009);

- the influence of international scholars (Tipton 1985, Gunter 2002a, 2002b, 2012a, 2012c) and

- the preparation and development of leaders (Gunter 2005, 2012b, Gunter and Fitzgerald 2008, Gunter and Thomson 2010).

Gender and/or women specifically feature in some of this writing (Gunter 2001, 2002a, 2002b, 2003a, 2004, 2005, 2012a, 2012b, Gunter and Ribbins 2002, 2003a, 2003b, Ribbins and Gunter 2002, Gunter and Fitzgerald 2007, 2008, Gunter and Thomson 2009, 2010). Emerging themes regarding gender include:

- identity construction (alongside age, disability, race and sexuality, for example) (Gunter 2001, Gunter and Ribbins 2003a, Gunter and Fitzgerald 2007, Gunter and Thomson 2009),

- issues of social injustice with regard to power struggles, division of labour and career paths (Gunter 2001, 2003a, 2004, 2005, Ribbins and Gunter 2002, Gunter and Ribbins 2003a, 2003b, Gunter and Thomson 2010),

- women's adoption of male/masculine/masculinist and/or 'normative' leadership (Gunter 2001, 2003a, Gunter and Thomson 2009) and

- as a focus for a continuing research agenda (Gunter 2001, 2002a, 2003a, Gunter and Ribbins 2002, 2003a, 2003b, Gunter and Fitzgerald 2008).

These women academics writing about women and/or gender reference: Sue Adler (Adler et al. 1993), Jill Blackmore (1989, 1999), Michele Bowring (2004), Marianne Coleman (2003), Tanya Fitzgerald (2003), Helen Gunter (McNamara et al. 2010), Valerie Hall (1996, 1999), Sharon Kruse (Kruse and Prettyman 2008), Jenny Laney (Adler et al. 1993), Olwen McNamara (McNamara et al. 2010), Mary Packer (Adler et al. 1993), Sandra Prettyman 
(Kruse and Prettyman 2008), Judyth Sachs (Blackmore and Sachs 2007) and Anna Yeatman (1990).

In a paper key to this search for women, Gunter (2000) critiques academics who otherwise take risks with theory, such as Baron and Taylor (1969), for being more involved with developing practitioner capability than in developing the intellectual foundation of the field. There are 'intellectual places where field members do not go or are unwilling to go' (Gunter 2000, p. 629). Their reticence results in gendered theory that:

continues to be used rather than problematised. The emphasis on scientific and rational knowledge claims remains an enduring feature within the field, and the problematic nature of this is located in claims about neutrality. (Gunter 2000, p. 630)

Feminist scholarship is used to problematise gendered leadership theory (Adler et al. 1993); the endurance of existing power structures (Blackmore 1989) and the experience of 'femocrats' as highly paid women who share with economically disadvantaged women the silencing of structural injustice (Yeatman 1990). Professionally successful women face the dilemma of losing power, once they challenge the masculine power structures, 'weakening their privileged position... could undermine their radical project' (Gunter 2000, p. 630). They are simultaneously powerful and powerless (Butler 1997, Baxter 2008).

595 Once this special edition is published, the group of women writers who have cited Baron and Taylor's (1969) book will include contributors who also write about gender and educational leadership: Jacky Lumby as a single author (Lumby 2006, 2009a, 2009b, 2009c, 2011, 2013) and co-author (Morrison et al. 2006, Lumby and Coleman 2007, Lumby et al. 2007, Morrison et al. 2007, Morrison and Lumby 2009, Lumby Morrison 2010, Heystek and Lumby 2011, Lumby and Azaola 2011, B, Lumby and Heystek 2012), Eugenie Samier (see Samier 2000, 2008, Samier et al. 2006, Samier and Schmidt 2009, 2010) and Kay Fuller (see Fuller 2009, 2010, 2013, in p. SP.

In the discussion that follows, I contend that through succeeding waves of feminism there remains a concern regarding the instability of women's positions in relation to power and feminist approaches to educational administration.

\section{Discussion}

The analysis of language, women's representation and intertextuality in Baron and Taylor's (1969) book has enabled an exploration of women in educational administration through succeeding historically located waves of feminism.

615 Feminist scholarship that developed during 'second wave' feminism and has matured in 'third wave' feminism, has been recognised for its powerful 
contribution to critical leadership studies (see Grace 2000). The women academics, whose writing was cited by Baron and Taylor (1969), acknowledged women's contributions to educational administration. Those whose writing cites Baron and Taylor (1969) go further by problematising leadership theory for its perpetuation of a masculinist approach to exercising power. They also challenge and change the discourse of knowledge produen. In the introduction to a special edition of this journal Helen Gunter and gerald (2007) tell their own stories about educational experiences and research. They 'privilege personalised, confessional, autobiographical or narrative writing' (Baxter 2003). It is an approach adopted by other researchers in the field who give lengthy accounts of headship in respondents' own words (Adler et al. 1993, Ozga 1993, Ribbins and Marland 1994, Hustler et al. 1995, Duffy 1999). More recently women academics have recounted their relationships with leadership for social justice by drawing on their autobiographies (Lyman et al. 2012). In 'Helen's story' and 'Tanya's story' (Gunter and Fitzgerald 2007), each reveals alternating senses of educational and social justice and injustice. Each found individuals who 'awakened my own sense of self, identity and agency and with events, however coincidental, that provided structure and purpose to my theorizing and professional practice as a researcher and teacher' (p. 8). Those individuals included women and men. A particularly vivid picture of resistance of authority by women is of nuns playing rugby 'veils flying' (p. 7).

Gunter (2013) resists conventional academic discourse in her use of poetry written by seminar participants. Gunter and Thomson $(2009,2010)$ draw on cultural studies and popular media as a lens through which to explore educational leadership (see also Gunter 1997, Thomson 2009). The television 'makeover' of women is a metaphor for leadership development (Gunter and Thomson 2009). Normative gender embodiments and enactments presented in various programmes targeted largely at women are linked with leadership makeover:

Class and gender are not available for deconstruction. Rather, particular classed, gendered and raced stereotypes are reinforced through the makeover. (p. 476)

Gender and class categories are re-made in the image of the presenters. Thus, Gunter and Thomson $(2009$, p. 477) challenge the normative leadership makeover that 'shunts aside larger questions of class, economy, gender and race' by focussing more on standards and test results, managing diversity and imposing a 'professional' identity that extends to what should be worn (see Fuller 2010).

Similarly, the BBC television crime drama Life on Mars is used to explore historical changes by ' $\mathrm{go}$ [ing] back in time to contemporary and historical practices of headship in English schools' (Gunter and Thomson 2010, p. 203). Gunter and Thomson (2010) refer to 'Sam (Samuel or Samantha) as Headteacher' waking up in 1973. Time travel as it is used in the programme and in Gunter and Thomson's (2010) exploration enables us to look at socio-cultural 
practices as well as employment. Legislation such as the Equal Pay Act 1970, Sex Discrimination Act 1975 and the Race Relations Act 1976 did not necessarily change attitudes and practice, 'there is evidence that actual practice still falls far short of the law, not least in relation to employment, and where the enquiry in to police practice over the death of Stephen Lawrence identified the endurance of institutionalised racism' (p. 219). Samuel and Samantha as headteachers would wake up in 1973 to different experiences of gender relations:

he would wake up in a different man's world to the one he inhabits today. Samantha would wake up in a particular type of man's world, and she would experience the discrimination that research has continued to demonstrate exists in the modern school as a workplace. (p. 220)

Sexist attitudes remain raising 'questions about social and political change, and the interplay between legitimate lawful regulation and the actual practices that are evident in everyday working lives' (p. 220). They force us to recognise how far (or not) gender relations have developed as equitable practices in employment, education and society.

In hindsight, the women remembered by history appear to be powerful. The 'first wave' feminists such as those named here, Emily Davies (1830-1921), Elizabeth Garrett (1836-1917) and Gertrude Denman (1885-1954), have been lauded for their achievements privileged though they may have been (see Australian Women's Archives Project, 2013 for an account of Gertrude Denman's time in Australia). There is no scope here to explore the biographies of these women in detail. However, a conversation between Emily Davies, Elizabeth and Millicent Garrett reveals their intentions regarding women's advancement (Kent 2005). Emily Davies planned to secure higher education for women (see Davies 1866), Elizabeth Garrett would open up the medical profession and Millicent Garrett must secure the vote for women. Elizabeth Garrett, the first British woman to qualify as a physician and surgeon, was elected to the School Board in 1870 with more votes than had ever before been cast in an election (Hollis 2013). She not only secured a place in a profession wholly dominated by men, but secured a popular vote among the electorate. By 1884, women had campaigned for anti-slavery, temperance, Corn Law repeal, undertaken philanthropic work in the roughest city streets with prostitutes, the diseased, drunks, tramps and feral-abused children (Hollis 2013). They had experience of local government as voters and as locally elected representatives (Hollis 2013). Such women were activists for what they saw to be the common good.

However, these women also appear to be powerless. Despite their campaigning, women were not granted suffrage until 1928. Kent (2005, p. 13) identifies securing the vote as

the symbol of the free, sexually autonomous woman and the means by which the goals of a feminist sexual culture were to be attained. ... the demand for women's 
enfranchisement was a direct strike at the very seat and symbolic locus of patriarchal power.

Some women sacrificed personal liberty to achieve greater freedoms as campaigns became more militant. However, campaigners such as Emily Davies and Millicent Garrett Fawcett distanced themselves from militancy and particular campaigns such as the repeal of the Contagious Diseases Acts 'neither wanted a breath of scandal attached to [Davies'] cause' (Kent 2005, p. 10). There is a sense of the instability of women's power that resonates with Yeatman's (1990) femocrats. Emily Davies had argued for women's education and entry into the professions as an avoidance of idleness among the middle and upper classes, possibly ignoring working class women who campaigned for women's suffrage and experienced 'domestic unhappiness' as a result of their involvement (Purvis 1995, p. 95). For some, protest impacted greatly on their personal lives; publically they were represented as 'wild' (see Billington 1982). The fluctuations between apparent powerfulness and powerlessness are dramatic.

Some headmistresses were concerned with suffrage for women though by no means all (Watts 1998). Elizabeth Wolstenholme (1833-1918) of the Manchester Schoolmistresses' Association campaigned about prostitution and was clearly 'prepared to tread such socially delicate ground while still practising as a teacher' (Abrams 2003, p. 4). However, her cohabitation with Ben Elmy was so radical that 'she would be all but written out of the histories of the respectable parts of the suffrage movement for many years to come' (Abrams 2003 , p. 6). The perceived scandal of her private actions reduced her public power. As a collective, and individually, headmistresses expressed opinions. How far these women were 'revolutionaries' is unclear (Glenday and Price 1974). They may have led reform in girls' education, but what is constructed as curriculum innovation and a refusal to 'slavishly imitat(e) their male counterparts' (Watts 1998, p. 349) might also be seen as developing a highly gendered curriculum still in place in the second half of the twentieth century (Gunter and Fitzgerald 2007).

Women who gained political power in the twentieth century such as Shena Simon (1880-1972, Member of Manchester City Council 1924-1934, coopted member of the Education Committee to 1970) (see Martin 2003), Alice Bacon (1909-1993, Member of Parliament 1945-1970) and Ellen Wilkinson (1891 - 1947, Member of Parliament 1924-1931 and 1935-1947) came from a variety of backgrounds. Like many Victorian and Edwardian philanthropists, Shena Simon's background was privileged. Promoting the common good was a moral priority and her commitment was to education and feminist activi745 ties and debates (Martin 2003). Her prediction that by 2022 half the parliamentary seats would be held by women is still a long way off (see Duckworth and Cracknell 2013 for an account of women's representation in parliament since 1918). Ellen Wilkinson and Alice Bacon, each from working class 
backgrounds, were on opposite sides of the comprehensive education debate (Benn 1980). The former has been criticised for seeing comprehensive education as merely experimental; the latter was an advocate of it (Benn 1980). Ellen Wilkinson was committed to a collective ministry, non-political view of education. Indeed, Benn (1980) has seen the delay in establishing comprehensive schooling as having wider causes than just Ellen Wilkinson's views. Government failed to recognise the political nature of education, listen to the wider Party including educationists and anticipate the popularity of comprehensive education. By attributing the delay to comprehensivisation to collective responsibility, Benn (1980) reveals the potential powerlessness of women in political office.

\section{Conclusion}

To conclude, most of the women discussed in this paper do not feature in Baron and Taylor's (1969) book at all. An FPDA focus on language and representation revealed how far the male-dominated discourse prevails in the text. It makes plain women's absence. I do not believe Baron and Taylor (1969) deliberately used their text to establish, confirm or legitimate an abuse of power (Blackledge 2005). Rather, it was written by men drawing on masculinised academic conventions to reflect a male-dominated field despite the social change occurring in the educational system and wider society. Nevertheless, its impact in marginalising women and women's educational administration is more important than its intent (see Shakeshaft 1987, Blackmore 1989, Coleman 2012).

FPDA has revealed a changing discourse regarding gender and educational administration. The absence of women in the text was identified by the initial focus on women and men using an essentialist approach. The inclusion of women in related texts enabled distinctions about powerful women with regard to social class. Vulnerable men featured in Cruickshank's (1963) text to demonstrate men can be powerless too. The unstable nature of power in the lives of seemingly powerful women demonstrates dramatic fluctuations between powerfulness and powerlessness in individual lives depending on context and circumstances. The exploration of interrelated texts by contemporary writers reveals the extent of their challenge to academic conventions, gendered theory and knowledge production.

Only by using an FPDA focus on intertextuality have women's contributions to educational administration as professionals, public servants and academics been surfaced here. This account has located women in particular historical moments that have been characterised as first, second and third waves of feminism. However, like Baxter (2003) I prefer to see these approaches to gender theory as strands of feminist history that not only compete and appear incompatible but also intertwine. As long as sexism remains in the family, education and the workplace, there remains a need to 
draw on feminist theories of equality and difference, outdated though they sometimes seem. By drawing on poststructural gender theory to question our assumptions of what is meant by 'woman', 'gender' and 'feminism' we might enable an inclusive and dialogic approach to leadership theory.

Reviewing publications in another journal over the course of 40 years about leadership and diversity, Coleman (2012) identified a lack of material about ethnicity, religion and sexual orientation as well as gender. There is clearly a need for research that focuses on intersectionality that draws on Critical Race Theory and Intersectionality Theory (Crenshaw 1991) to recount the experiences of Black and Global Majority women (and men) in educational administration. The Coalition government, from 2010, has prioritised tackling homophobia in schools. There is also a need for research into lesbian gay bisexual transgendered and questioning women and men in educational administration. In its identification of nine protected characteristics, the UK Equality Act (2010) provides a starting point for research into understanding the impact of diversity on becoming and being educational administrators and on leading staff and students.

\section{Notes on contributor}

Kay Fuller is a Lecturer in Education at the University of Birmingham. Her main research interests are in gender and educational leadership. She has also worked in secondary school senior leadership and in retail management.

\section{References}

Abrams, F., 2003. Freedom's cause: lives of the suffragettes. London: Profile Books. Acker, S., 2012. Chairing and caring: gendered dimensions of leadership in academe. Gender and education, 24 (4), 411-428.

Adler, S., Laney, J., and Packer, M., 1993. Managing women: feminism and power in educational management. Buckingham: Open University Press.

Australian Women's Archives Project, 2013. From Lady Denman to Katy Gallagher a century of women's contributions to Canberra. Available from: http://www. womenaustralia.info/exhib/ldkg/introduction.html [Accessed 20 December 2013].

Austwick, K., 1969. Administration and educational technology. In: G. Baron and W. Taylor, eds. Educational administration and the social sciences. London: The Athlone Press, 144-158.

Banks, O., 1955. Parity and prestige in English secondary education. London: Routledge and Kegan Paul.

Banks, O., 1982. The sociology of education, 1952-1982. British journal of educational studies, 30 (1), 18-31.

Banks, O., 1999. Some reflections on gender, sociology and women's history. Women's history review, 8 (3), 401-410.

Banks, J. and Banks, O. 1964. Feminism and family planning in Victorian England. Liverpool: Liverpool University Press.

Baron, G., 1969. The study of educational administration. In: G. Baron and W. Taylor, eds. Educational administration and the social sciences. London: The Athlone Press, 3-17. 
Baron, G. and Taylor, W., 1969. Educational administration and the social sciences. London: The Athlone Press.

Baxter, J., 2003. Positioning gender in discourse. Basingstoke: Palgrave Macmillan.

Baxter, J., 2008. Feminist post-structuralist discourse analysis - a new theoretical and methodological approach? In: K. Harrington et al., eds. Gender and language research methodologies. London: Palgrave Macmillan, 243-255.

Benn, C., 1980. Comprehensive school reform and the 1945 labour government. History workshop, 10 (1), 197-204.

Billington, R., 1982. Ideology and feminism: why the suffragettes were 'wild' women. Women's studies international forum, 5 (6), 663-674.

Blackledge, A., 2005. Discourse and power in a multilingual world. Amsterdam: John Benjamins.

Blackmore, J., 1989. Educational leadership: a feminist critique and reconstruction. In: J. Smyth, ed. Critical perspectives on educational leadership. London: Falmer, 93-129.

Blackmore, J., 1999. Troubling women. Buckingham: Open University Press.

Blackmore, J. and Sachs, J., 2007. Performing and reforming leaders: gender, educational restructuring and organizational change. Albany: State University of New York Press.

Bondi, L., 1997. In whose words? On gender identities, knowledge and writing practices. Transactions of the institute of British geographers, New Series, 22 (2), 245-258.

Bowring, M., 2004. Resistance is not futile: liberating captain Janeway from the masculine-feminine dualism of leadership. Gender, work and organization, 11 (4), 381 405.

Burnham, P., 1969. Role theory and educational administration. In: G. Baron and W. Taylor, eds. Educational administration and the social sciences. London: The Athlone Press, 72-96.

860 Burstall, S., 1910. The school world, September.

Butler, J., 1990. Gender trouble. London: Routledge.

Butler, J., 1997. The psychic life of power: theories in subjection. Stanford, CA: Stanford University Press.

Butler, J., 2004. Undoing gender. New York: Routledge.

Centre for Advancement of Women in Politics at Queens University, Belfast, Observatory. Available from: http://www.qub.ac.uk/cawp/observatory.html [Accessed 13 November 2013].

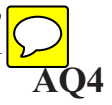

Coleman, M., 2003. Gender and the orthodoxies of leadership. School leadership \&

management, 23 (3), 325-339.

Connell, R., 2005. Masculinities. 2nd ed. Los Angeles: University of California Press.

Cooper, G., 2007. Why women love DCI hunt. The Telegraph. Available from: http://

Dwww.telegraph.co.uk/news/features/3632103/Why-women-love-DCI-Hunt.html [Accessed 2 January 2014].

Crenshaw, K., 1991. Mapping the margins: intersectionality, identity politics, and violence against women of color. Stanford law review, 43 (6), 1241-1299.

Cruickshank, M., 1963. Church and state in English education. London: Macmillan.

Davies, E., 1866. The higher education of women. London: Alexander Strahan.

Department for Education, 2012. School workforce in England: November 2011. Available from: www.education.gov.uk/rsgateway/DB/SFR/s001062/index.shtml [Accessed 9 January 2014].

Donnison, D. and Chapman, V., 1965. Formulating a policy for secondary education in Croydon. In: D. Donnison and V. Chapman, eds. Social policy and administration. London: Allen and Unwin, 201-299. 
Donnison, D., et al., 1970. Social policy and administration. London: Allen and Unwin.

Duckworth, N. and Cracknell, R. 2013. Women in parliament and government. Available from: http://www.parliament.uk/briefing-papers/SN01250/women-inparliament-and-government [Accessed 2 January 2014].

Duffy, E., 1999. Leading the creative school. In: H. Tomlinson, H. Gunter, and P. Smith, eds. Living headship: voices, values and vision. London: Paul Chapman, 105-113.

Eggleston, S.J., 1969. The social context of administration. In: G. Baron and W. Taylor, eds. Educational administration and the social sciences. London: The Athlone Press, $18-35$.

Feminist Archive North. A chronology of the women's liberation movement in Britain. Available from: http://www.feministarchivenorth.org.uk/chronology/ [Accessed 6 November 2013].

Fitzgerald, T., 2003. Interrogating orthodox voices: gender, ethnicity and educational leadership. School leadership and management, 23 (4), 431-444.

Friedan, B., 1963. The feminine mystique. London: Gollancz.

Fuller, K., 2009. Women secondary head teachers: alive and well in Birmingham at the beginning of the twenty-first century. Management in education, 23 (1), 19-31.

Fuller, K., 2010. Talking about gendered headship: how do women and men working in schools conceive and articulate notions of gender? Journal of educational administration and history, 42 (4), 363-382.

Fuller, K., 2013. Gender, identity and educational leadership. London: Bloomsbury.

900 Fuller, K., in press. Gendered educational leadership: beneath the monoglossic façade. Gender and Education.

Glenday, N. and Price, M., 1974. Reluctant revolutionaries: a century of headmistresses 1874-1974. London: Pitman.

Grace, G., 1995. School leadership. London: The Falmer Press.

Grace, G., 2000. Research and the challenges of contemporary school leadership: the contribution of critical scholarship. British journal of educational studies, 48 (3), $231-247$.

Gray, H., 1989. Gender considerations in school management: masculine and feminine leadership styles. In: C. Riches and C. Milton Keynes: Open University Pres 2

Gunter, H., 1997. Rethinking education: the consequences of Jurassic management.

910 London: Cassell. Wales. British journal of sociology of education, 21 (4), 623-635.

Gunter, H., 2001. Leaders and leadership in education. London: Paul Chapman.

Gunter, H., 2002a. Purposes and positions in the field of education management: putting Bourdieu to work. Educational management and administration, 30 (2), $7-26$.

Gunter, H., 2002b. International networking and the development of the field of education management in the UK. Journal of educational administration and history, 34 (2), 92-105.

Gunter, H., 2003a. Introduction - the challenge of distributed leadership. School leadership \& management: formerly school organisation, 23 (3), 261-265.

Gunter, H., 2003b. Thinking through moral values: putting Bourdieu to work in the field of education management. In: E. Samier and K. Mihailova, eds. Ethical foundations for educational administration. Abingdon: Routledge, 212-234.

Gunter, H., 2004. Labels and labelling in the field of educational leadership. Discourse: studies in the cultural politics of education, 25 (1), 21-41. 
925 Gunter, H., 2005. Conceptualizing research in educational leadership. Educational management administration and leadership, 33 (2), 165-180.

Gunter, H., 2012a. The field of educational administration in England. British journal of educational studies, 60 (4), 337-356.

Gunter, H., 2012b. Academic work and performance. In: T. Fitzgerald, J. White, and H. Gunter, eds. Hard labour? Academic work and the changing landscape of higher education. Bingley: Emerald Group, 65-85.

Gunter, H., 2012c. BELMAS: perspectives on origins and development. Paper presented at BELMAS conference, leadership and policy in education: looking back to look forward, 21 November, Birmingham.

Gunter, H., 2013. Why we 'knead' theory. Management in education, 27 (1), 4-6.

Gunter, H. and Fitzgerald, T., 2007. The contribution of researching professionals to field development: introduction to a special edition. Journal of educational administration and history, 39 (1), 1-16.

Gunter, H. and Fitzgerald, T., 2008. The future of leadership research? School leadership \& management: formerly school organisation, 28 (3), 261-279.

Gunter, H. and Ribbins, P., 2002. Leadership studies in education towards a map of the field. Educational management administration and leadership, 30 (4), 387-416.

Gunter, H. and Ribbins, P., 2003a. The field of educational leadership: studying maps and mapping studies. British journal of educational studies, 51 (3), 254-281.

Gunter, H. and Ribbins, P., 2003b. Challenging orthodoxy in school leadership studies: knowers, knowing and knowledge? School leadership \& management, 23 (2), 129-147.

Gunter, H. and Thomson, P., 2009. The makeover: a new logic in leadership development in England. Educational review, 61 (4), 469-483.

Gunter, H. and Thomson, P., 2010. Life on mars: headteachers before the National College. Journal of educational administration and history, 42 (3), 203-222.

Hall, V., 1996. Dancing on the ceiling. London: Paul Chapman.

Hall, V., 1999. Gender and education management: duel or dialogue? In: T. Bush et al., eds. Educational management: redefining theory, policy, and practice. London: Paul Chapman, 155-165.

Heystek, J. and Lumby, J., 2011. Identity and diversity: a case study of leaders in a South African primary school. Education as change, 15 (2), 331-343.

Hollis, P., 2013. The hopes of the suffragettes: were they realised? TV, BBC Parliament, November 6. Available from: http://www.bbc.co.uk/iplayer/episode/ b03mthm1/Suffragettes_Lecture/ [Accessed 2 January 2014].

Hoyle, E., 1969. Organisation theory and educational administration. In: G. Baron and W. Taylor, eds. Educational administration and the social sciences. London: The Athlone Press, 36-59.

Hustler, D., Brighouse, T., and Ruddock, J., 1995. Heeding heads: secondary heads and commentators in dialogue. London: David Fulton.

Incorporated Association of Headmistresses, 1910. Report of the executive committee, October.

Incorporated Association of Headmistresses, 1926. Annual report.

Ingraham, I., 1994. The heterosexual imaginary: feminist sociology and theories of gender. Sociological theory, 12 (2), 203-219.

Kent, S., 2005. Sex and suffrage in Britain 1860-1914. Taylor and Francis e-Lilbrer.

Kruse, S. and Prettyman, S., 2008. Women, leadership, and power revisiting the wicked witch of the West. Gender and education, 20 (5), 451-464. 
Luke, A., 1995. Text and discourse in education: an introduction to ${ }^{\text {al discourse }}$ analysis. In: M.W. Apple, ed. Review of research in education, $N$ Washington, DC: American Educational Research Association, 3-48.

Lumby, J., 2006. Conceptualizing diversity and leadership. Educational management administration and leadership, 34 (2), 151-165.

Lumby, J., 2009a. Performativity and identity: mechanisms of exclusion. Journal of education policy, 24 (3), 353-369.

Lumby, J., 2009b. Disappearing gender: choices in identity. In: H. Sobehart, ed. Women leading education across the continents: sharing the spirit, fanning the flame. Lanham, MD: Rowman and Littlefield with the American Association of School Administrators, 29-40.

Lumby, J., 2009c. Leaders' orientations to diversity: two cases from education. Leadership, 5 (4), 423-446.

980 Lumby, J., 2011. Gender representation and social justice: ideology, methodology and smoke-screens. Gender and education, 23 (7), 921-934.

Lumby, J., 2013. Valuing knowledge over action: the example of gender in educational leadership. Gender and education, 25 (4), 432-443.

Lumby, J. and Azaola, C., 2011. Women principals in small schools in South Africa. Australian journal of ention, 55 (1), 73-85.

Lumby, J. and Azaola, M., LOT3. Women principals in South Africa: gender, mothering and leadership. British educational research journal.

Lumby, J. and Coleman, M., 2007. Leadership and diversity. London: Sage.

Lumby, J. and Heystek, J., 2012. Leadership identity in ethnically diverse schools in South Africa and England. Educational management administration and leadership, 40 (1), 4-20.

Lumby, J. and Morrison, M., 2010. Leadership and diversity: theory and research. School leadership \& management: formerly school organisation, 30 (1), 3-17.

Lumby, J., et al., 2007. Integrating diversity in leadership in further education. Research report. Lancaster: Centre for Excellence in Leadership.

Lyman, L., Strachan, J., and Lazaridou, A., 2012. Shaping social justice leadership. Lanham, MD: Rowman and Littlefield.

995 Martin, J., 2003. Shena D. Simon and English education policy: inside/out? History of education: journal of the history of education society, 32 (5), 477-494.

Martin, J., 2008. Beyond suffrage: feminism, education and the politics of class in the inter-war years. British journal of sociology of education, 29 (4), 411-423.

McNamara, O., Fryer, A., Gunter, H. and Howson, J., 2010. Gender in leadership. Report to the NASUWT. Birmingham: NASUWT.

1000 Morley, L., 2013a. Women and higher education leadership: absences and aspirations. London: Leadership Foundation for Higher Education.

Morley, L., 2013b. The rules of the game: women and the leaderist turn in higher education. Gender and education, 25 (1), 116-131.

Morrison, M. and Lumby, J., 2009. Is leadership observable? Qualitative orientations to leadership for diversity. A case from FE. Ethnography and education, 4 (1), 65-82.

Morrison, M., Lumby, J., and Sood, K., 2006. Diversity and diversity management: messages from recent research. Educational management administration and leadership, 34 (3), 277-295.

Morrison, M., et al., 2007. Diversity, identity and leadership. Research report. Lancaster: Centre for Excellence in Leadership.

Myers, C., 1969. Operational research in educational administration. In: G. Baron and W. Taylor, eds. Educational administration and the social sciences. London: The Athlone Press, 159-173. 
Ouston, J., 1993. Women in education management. Harlow: Longman.

Owen, J., 1969. Administration and curriculum change. In: G. Baron and W. Taylor, eds. Educational administration and the social sciences. London: The Athlone Press, $124-143$.

Ozga, J., 1993. Women in educational management. Buckingham: Open University Press.

Pedersen, J., 1987. The reform of girls' secondary and higher education in Victorian England. London: Garland.

1020 Peston, M., 1969. Economics and administration of education. In: G. Baron and W. Taylor, eds. Educational administration and the social sciences. London: The Athlone Press, 60-71.

Phillips, M., 1965. Small social groups in England. London: Methuen.

Purvis, J., 1995. Deeds, not words the daily lives of militant suffragettes in Edwardian Britain. Women's studies international forum, 18 (2), 91-101.

1025 Ribbins, P. and Gunter, H., 2002. Mapping leadership studies in education towards a typology of knowledge domains. Educational management and administration, 30 (4), 359-385.

Ribbins, P. and Marland, M., 1994. Headship matters. Harlow: Longman.

Roth, B., 2004. Separate roads to feminism. Cambridge: Cambridge University Press.

Samier, E., 2000. Public administration mentorship: conceptual and pragmatic considerations. Journal of educational administration, 38 (1), 83-101.

Samier, E., 2008. Political approaches to educational administration and leadership. Abingdon: Routledge.

Samier, E. and Schmidt, M., 2009. Emotional dimensions of educational administration and leadership. Abingdon: Routledge.

Samier, E. and Schmidt, M., 2010. Trust and betrayal in educational administration and leadership. Abingdon: Routledge.

Samier, E., Bates, R., and Stanley, A., 2006. Aesthetic dimensions of educational administration \& leadership. Abingdon: Routledge.

Scott, J., 1988. Deconstructing equality-versus-difference: or, the uses of poststructuralist theory for feminism. Feminist studies, 14 (1), 32-50.

Shakeshaft, C., 1987. Women in education administration. New York: Sage.

1040 Simon, S., 1948. Three schools or one. London: Frederick Muller.

Stout, L., 2012. A matter of simple justice: the untold story of Barbara Hackman Franklin and a few good women. Pennsylvania: The Pennsylvania State University Libraries.

Taylor, W., 1969. Issues and problems in training the school administrator. In: G. Baron and W. Taylor, eds. Educational administration and the social sciences. London: The Athlone Press, 97-123.

Thompson, B., 2002. Multiracial feminism: recasting the chronology of second wave feminism. Feminist studies, 28 (2), 336-360.

Thomson, P., 2009. School leadership: heads on the block. Abingdon: Routledge.

Tipton, B., 1985. Educational organisations as workplaces. British journal of sociology of education, 6 (1), 35-53.

1050 Walkerdine, V., 1990. Schoolgirl fictions. London: Verso.

Watts, R., 1998. From lady teacher to professional: a case study of some of the first headteachers of girls' secondary school in England. Educational management administration and leadership, 26 (4), 339-351.

Wheeler, G., 1969. The administration of the larger educational unit. In: G. Baron and W. Taylor, eds. Educational administration and the social sciences. London: The Athlone Press, 174-188. 
Williams, D., 1998. Women leaders: past, present, and emerging. Available from http://people.brandeis.edu/ dwilliam/docs/leadertable.htm [Accessed 2 January 2014].

1060

Yeatman, A., 1990. Bureaucrats, technocrats, femocrats. Essays on the contemporary Australian state. Sydney: Allen and Unwin.

1065

1070

1075

1080

1085

1090

1095 